\title{
Genetic correlation and path analysis of common bean collected from Caceres Mato Grosso State, Brazil
}

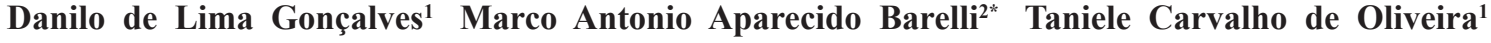 \\ Paulo Ricardo Junges dos Santos ${ }^{1}$ Claudete Rosa da Silva ${ }^{3}$ \\ Juliana Parisotto Poletine ${ }^{4}$ Leonarda Grillo Neves ${ }^{2}$ \\ ${ }^{1}$ Universidade do Estado de mato Grosso (UNEMAT), Cáceres, MT, Brasil. \\ ${ }^{2}$ Departamento de Agronomia, Universidade do Estado de mato Grosso (UNEMAT), 78.200-000, Cáceres, MT, Brasil. E-mail: mbarelli@unemat.br. \\ ${ }^{*}$ Corresponding author. \\ ${ }^{3}$ Universidade Federal Rural da Amazônia (UFRA), Parauapebas, PA, Brasil. \\ ${ }^{4}$ Departamento de Ciências Agronômicas, Universidade Estadual de Maringá (UEM), Umuarama, PR, Brasil.
}

\begin{abstract}
The aim of the study was to determine genetic correlations of agronomic traits and to evaluate direct and indirect effects, through path analysis, between variables analyzed with grain yield. Forty accessions of common bean, cultivated at Caceres County were evaluated, by using randomized complete blocks design with three repetitions. Coefficient magnitudes of genotypic correlations were superior to phenotypic and environmental ones for most correlations, suggesting greater influence of genetic factor than environmental factors. In order to determine the importance of direct and indirect effects, path analysis was performed, which provided greater reliability in interpretations of cause and effect between studied traits, indicating that grain yield may be explained by the effects of analyzed traits. Number of seeds per plant (0.801) and grain weight (0.641) showed higher favorable effect over grain yield, allowing its use in direct or indirect selection for grain yield in common bean. Key words: agronomic traits, correlation coefficient, crop breeding, Phaseolus vulgaris L., grains yield.
\end{abstract}

\author{
Correlação genética e análise de trilha de feijão \\ comum coletados em Cáceres-MT, Brasil
}

RESUMO: O objetivo do presente trabalho foi determinar as correlações genéticas entre caracteres e avaliar os efeitos diretos e indiretos, entre as variáveis analisadas com a produtividade de grãos, por meio de análise de trilha. Foram avaliados 40 acessos de feijoeiro comum cultivados na Empaer de Cáceres, adotando o delineamento de blocos ao acaso, com três repetições. As magnitudes dos coeficientes de correlações genotípicas foram superiores as ambientais e fenotípicas para a maioria das correlações, evidenciando maior influência do fator genético do que dos fatores ambientais. Os efeitos diretos e indiretos proporcionaram maior confiabilidade nas interpretações de causa e efeito entre os caracteres estudados, indicando que a produtividade de grãos pode ser explicada por meio dos efeitos dos caracteres analisados. Os caracteres número de sementes por planta $(0,801)$ e peso de grão $(0,641)$ apresentaram maior efeito direto favorável, demonstrando forte associação entre os caracteres analisados, podendo ser utilizados na seleção direta ou indireta para a produtividade de grão em feijoeiro. Palavras chave: caracteres agronômicos, coeficiente de correlação, melhoramento genético, Phaseolus vulgaris L., produtividade de grãos.

\section{INTRODUCTION}

Common bean (Phaseolus vulgaris L.), food legume of great importance, is produced in many countries, whose cultivation ranges from low external input, even the use of modern production technologies (SILVA, 2007). Myanmar has standing out as the largest world beans production, followed by India, Brazil and China (FAO, 2012). Brazil presents higher grain yield than world average $\left(758 \mathrm{~kg} \mathrm{ha}^{-1}\right)$, just over $1000 \mathrm{~kg} \mathrm{ha}^{-1}$. Parana, Minas Gerais, Mato Grosso, São Paulo and Goias States, are the major producers, with crop cultivation in three different seasons throughout the year, providing a constant product supply on the market (CONAB, 2013).
Development of new genotypes with higher genetic potential for grain yield is the main goal of breeding programs, what, according to NOGUEIRA et al. (2012) throughout selection process, aimed to improve a main characteristic, maintaining or enhancing the expression of other simultaneously. Knowledge about existing relationships between traits, such as estimated by correlations, because of its great importance in crop improvement programs, helps in selection process.

Although, being really useful in quantifying the magnitude and direction of components influence in the determination of main characters, correlation coefficients did not provide the relative importance of direct and indirect effects of such components (SILVA 
et al., 2009). These may be determined through path analysis, with the unfolding of correlation coefficient for analyzed traits, in direct and indirect effect, providing greater reliability in interpretations of cause and effect between the studied traits.

Based on correlation estimates, it is possible to practice indirect selection for a major character, leading to faster progress, when compared to direct selection for desired character. Such correlations do not determine the relative importance of direct and indirect influences of other traits with production, since cause and effect relationship between them may be determined through path analysis, allowing the partition of correlations coefficients in both direct and indirect effects (CRUZ et al., 2012).

Grain yield is a complex feature, resulting from the expression and association of different production components that are considered by breeders in the selection process of new genotypes (AMORIM et al., 2008).

In this way, the research aimed to estimate genetic correlation between agronomic traits of importance to common bean crop and to evaluate direct and indirect effects between analyzed variables with grain yield by path analysis, making it easy genotypes selection in future common bean breeding programs.

\section{MATERIALS AND METHODS}

The research was conducted in an experimental area belonging to Empresa MatoGrossense de Pesquisa, Assistência e Extensão Rural (Empaer), in Caceres County, Mato Grosso State, located at $16^{\circ} 43^{\prime} 42^{\prime \prime} \mathrm{S}$ and $57^{\circ} 40^{\prime} 51 \mathrm{~W}$ with 118 meters altitude, at BR 070, $12 \mathrm{~km}$ from Caceres. Region climate, according to Köppen classification, is tropical, hot, humid and dry winter (Awa), with rainfall period ranging from October to March, and drought from April to September (NEVES et al., 2011). Soil is classified as Argisoil Yellow Red Eutrophic chernossolic, medium-textured silty (ARANTES et al., 2012).

In this experiment it was used 40 traditional common bean accesses from Active Bank of Germplasm (ABG) of Phaseolus (Table 1) belonging to Universidade do Estado de Mato Grosso UNEMAT, Campus de Caceres. Previously it was collected soil samples for chemical analysis, taken to a depth of $0-10$ and $10-20 \mathrm{~cm}$. Subsequently, fertilization was performed, according to soil analysis and crop requirements: $40 \mathrm{~kg}$ of urea applied per hectare, $350 \mathrm{~kg}$ ha $^{-1}$ of Super Triple Phosphate at sowing (without potassium requirement), in April, 2013, with a density of 10 seeds per linear meter and plant spacing of $0.1 \mathrm{~m}$ and $0.5 \mathrm{~m}$ between rows.

Randomized complete blocks design with three repetitions was used. Experimental plots were constituted by four rows of $4 \mathrm{~m}$ length, with $0.5 \mathrm{~m}$ spacing and sowing density of 10 seeds per meter according to CABRAL et al. (2011), analyzing only useful area, corresponding to two central rows of each plot.

Basic management measures were adopted, such as hand weeding, in order to do not promote damages to the initial crop development. Irrigation sprinkler was held when necessary, aiming to supplying hydro needs for crop development. Insecticides application was conducted whenever necessary, according to the level of insect's infestation and crop development cycle.

The following agronomic traits were evaluated: a) number of days to flowering (NDF): obtained by counting the number of days from sowing to the complete opening of first flower, in $50 \%$ of plants in each plot; b) height of insertion first pod (HFPI): in cm, measured with a ruler graduated, obtained by measurement of the soil base by inserting the first pod, evaluating ten plants per plot; c) final plants height $(\mathrm{FPH})$ : expressed in $\mathrm{cm}$, obtained by measurement, obtained from ground level until the extreme plant, using a graduated measuring tape, evaluating ten plants of each plot; d) longitudinal length of pods (LLP): expressed in $\mathrm{cm}$, obtained with a ruler graduated, measuring from one lengthwise extreme to another of pods with a random sample of ten pods of the ten evaluated plants per plot; e) total number of pods per plant (TNPP): obtained by the count of pods per plant, evaluated in each plot; f) number of seeds per pod (NSP): obtained by the score of a random sample of ten pods per plot; g) number of seeds per plant (NSPL): obtained by the average between the number of seeds produced per plant, in each of ten evaluated plants per plot; h) grain weight $(\mathrm{GW})$ : in grams $(\mathrm{g})$, obtained by weighing of four samples of 100 seeds of each plot, with moisture content of $12 \%$; i) cycle (CYCLE): obtained by the ratio of number of days from emergence until plants harvest, in each treatment; $j$ ) grain yield (YIELD): expressed in $\mathrm{kg} \mathrm{ha}^{-1}$, obtained by the ratio between the total weight of grains in each plot and plant number, converted to hectares. $\mathrm{K})$ hectoliter weight (HECTO): in $\mathrm{kg} \mathrm{hl}^{-1}$, analyzed by a moisture determination, with Agrologic (AL101 Portable), determining moisture content and hectoliter weight in each plot. 
Table 1 - Traditional common bean accesses from Active Germplasm Bank of Phaseolus belonging to UNEMAT (Cáceres-MT. 2013).

\begin{tabular}{|c|c|c|c|c|c|c|c|c|}
\hline $\mathrm{N}^{\circ}$ & Accesses & $\begin{array}{l}\text { Comercial } \\
\text { Group }\end{array}$ & $\begin{array}{c}\text { Flower } \\
\text { Color }\end{array}$ & $\begin{array}{l}\text { Seed } \\
\text { Color }\end{array}$ & $\begin{array}{l}\text { Halo } \\
\text { Color }\end{array}$ & $\begin{array}{l}\text { Growth } \\
\text { habit }\end{array}$ & $\begin{array}{c}\text { Seeds } \\
\text { Brightness }\end{array}$ & Genic Group \\
\hline 1 & BG-UNEMAT - 18 & Manteigão & White & 1 & 2 & Type III & 1 & Mesoamerican \\
\hline 2 & BG-UNEMAT - 28 & Manteigão & White & 1 & 2 & Type IV & 3 & Mesoamerican \\
\hline 3 & BG-UNEMAT - 11 & Bolinha & White & 1 & 2 & Type III & 1 & Andean \\
\hline 4 & BG-UNEMAT - 27 & Mulatinho & White & 1 & 2 & Type III & 1 & Mesoamerican \\
\hline 5 & BG-UNEMAT - 22 & Carioca & White & 2 & 2 & Type II & 3 & Mesoamerican \\
\hline 6 & BG-UNEMAT - 40 & Carioca & White & 2 & 2 & Type IV & 1 & Mesoamerican \\
\hline 7 & BG-UNEMAT - 17 & Preto & Purple & 1 & 2 & Type IV & 3 & Mesoamerican \\
\hline 8 & BG-UNEMAT - 32 & Manteigão & White & 1 & 2 & Type II & 1 & Mesoamerican \\
\hline 9 & BG-UNEMAT - 4 & Mulatinho & White & 1 & 2 & Type II & 3 & Mesoamerican \\
\hline 10 & BG-UNEMAT - 30 & Roxo & White & 1 & 1 & Type IV & 3 & Mesoamerican \\
\hline 11 & BG-UNEMAT - 3 & Manteigão & White & 1 & 2 & Type IV & 1 & Mesoamerican \\
\hline 12 & BG-UNEMAT - 6 & Carioca & White & 2 & 2 & Type IV & 1 & Mesoamerican \\
\hline 13 & BG-UNEMAT - 29 & Mulatinho & White & 1 & 2 & Type IV & 1 & Mesoamerican \\
\hline 14 & BG-UNEMAT - 35 & Manteigão & White & 1 & 1 & Type I & 1 & Mesoamerican \\
\hline 15 & BG-UNEMAT - 42 & Carioca & White & 2 & 2 & Type IV & 5 & Mesoamerican \\
\hline 16 & BG-UNEMAT - 23 & Carioca & White & 2 & 2 & Type IV & 3 & Mesoamerican \\
\hline 17 & BG-UNEMAT - 26 & Mulatinho & White & 2 & 2 & Type IV & 1 & Mesoamerican \\
\hline 18 & BG-UNEMAT - 31 & Mulatinho & White & 1 & 2 & Type III & 3 & Mesoamerican \\
\hline 19 & BG-UNEMAT - 37 & Roxo & White & 1 & 2 & Type II & 3 & Mesoamerican \\
\hline 20 & BG-UNEMAT - 38 & Manteigão & Purple & 2 & 2 & Type IV & 3 & Andean \\
\hline 21 & BG-UNEMAT - 75 & Carioca & White & 2 & 2 & Type IV & 1 & Mesoamerican \\
\hline 22 & BG-UNEMAT - 1 & Carioca & White & 1 & 2 & Type II & 1 & Mesoamerican \\
\hline 23 & BG-UNEMAT - 56 & Mulatinho & White & 1 & 2 & Type IV & 3 & Mesoamerican \\
\hline 24 & BG-UNEMAT - 50 & Carioca & White & 2 & 1 & Type I & 1 & Mesoamerican \\
\hline 25 & BG-UNEMAT - 49 & Carioca & White & 2 & 1 & Type IV & 1 & Mesoamerican \\
\hline 26 & BG-UNEMAT - 45 & Manteigão & White & 1 & 2 & Type II & 3 & Mesoamerican \\
\hline 27 & BG-UNEMAT - 46 & Carioca & White & 2 & 1 & Type IV & 1 & Mesoamerican \\
\hline 28 & BG-UNEMAT - 72 & Manteigão & White & 1 & 2 & Type IV & 1 & Mesoamerican \\
\hline 29 & BG-UNEMAT - 55 & Carioca & White & 2 & 1 & Type IV & 3 & Mesoamerican \\
\hline 30 & BG-UNEMAT - 16 & Manteigão & White & 1 & 2 & Type IV & 5 & Mesoamerican \\
\hline 31 & BG-UNEMAT - 60 & Manteigão & White & 1 & 2 & Type III & 1 & Mesoamerican \\
\hline 32 & BG-UNEMAT - 58 & Manteigão & White & 1 & 2 & Type IV & 1 & Mesoamerican \\
\hline 33 & BG-UNEMAT - 5 & Carioca & Roxa & 2 & 1 & Type IV & 1 & Mesoamerican \\
\hline 34 & BG-UNEMAT - 68 & Bolinha & White & 2 & 2 & Type III & 1 & Andean \\
\hline 35 & BG-UNEMAT - 7 & Manteigão & White & 2 & 1 & Type IV & 1 & Andean \\
\hline 36 & BG-UNEMAT - 47 & Roxo & White & 1 & 2 & Type II & 1 & Mesoamerican \\
\hline 37 & BG-UNEMAT - 12 & Carioca & White & 2 & 1 & Type II & 1 & Mesoamerican \\
\hline 38 & BG-UNEMAT - 13 & Carioca & White & 2 & 2 & Type III & 1 & Mesoamerican \\
\hline 39 & BG-UNEMAT - 20 & Carioca & White & 2 & 2 & Type IV & 1 & Mesoamerican \\
\hline 40 & BG-UNEMAT - 21 & Carioca & White & 2 & 2 & Type I & 3 & Mesoamerican \\
\hline
\end{tabular}

Halo Color: 1 same color of the seed and 2 different color of the seed; seed color: 1 uniform and 2 desuniform; growth habit: Type I = determined erect. Type II = undetermined erect. Type III = indeterminate prostrate. Type IV = indeterminate semi climber; seed brightness: $1=$ opaque. 3 = intermediary and $5=$ shiny.

For each one of the eleven traits evaluated, it was employed Simple Correlation Estimator Method, to assess phenotypic correlation coefficients, by " $\mathrm{t}$ " Test, and for genotypic and environmental correlation coefficients it was used bootstrap method with 1000 simulations.
In order to estimate phenotypic, genotypic and environmental correlation coefficients between two characters $(\mathrm{X}$ and $\mathrm{Y})$, it is recommended the individual analyses and the sum of $\mathrm{X}$ and $\mathrm{Y}$ values, such the mean products (covariance), may be associated with each variation source (CRUZ et al., 2012). 
Besides it, to classify correlations magnitude, it was used the classification proposed by Shimakura and RIBEIRO JUNIOR (2012) according to correlations magnitude, dividing into the following classes: from 0.0 to 0.19 -really mild; of 0.20 to 0.39 -mild; from 0.40 to 0.69 -moderate; from 0.70 to 0.89 -strong; and from 0.90 to 1.00-really strong was adopted.

For the analysis of direct and indirect effects over grain yield it was carried out path analyses between traits, with estimates obtained by means of regression equations, where traits are previously standardized, by using Genes computer program (CRUZ, 2013).

\section{RESULTS AND DISCUSSION}

Estimates of phenotypic, genotypic and environmental coefficient of correlations, represented in table 2 , ranging from -0.61 to $0.75 ;-0.87$ to 0.79 ; and -0.33 to 0.83 , respectively, with difference in the signal, in the direction, in the significance and magnitude of correlations for most evaluated traits.

In order to determine the magnitude of correlations, it was adopted the classification proposed by SHIMAKURA \& RIBEIRO JUNIOR (2012). From a total of 55 phenotypic correlations, only $36.36 \%$ were significant by " $t$ " test, independently

Table 2 - Estimates of phenotypic $\left(\mathrm{r}_{\mathrm{F}}\right)$, genotypic $\left(\mathrm{r}_{\mathrm{G}}\right)$ and environmental correlation coefficients $\left(\mathrm{r}_{\mathrm{E}}\right)$ among 11 studied traits evaluates in 40 common bean traditional accesses (Caceres-MT, 2013).

\begin{tabular}{|c|c|c|c|c|c|c|c|c|c|c|c|}
\hline Traits $^{\prime 1}$ & $\mathrm{R}$ & HFPI & FPH & LLP & TNPP & NSP & NSPL & GW & CYCLE & YIELD & HECTO \\
\hline \multirow{3}{*}{$\mathrm{NDF}$} & $r_{F}$ & $0.43^{* *}$ & -0.10 & -0.08 & $-0.33^{*}$ & $0.54^{* *}$ & 0.04 & -0.25 & $0.68^{* *}$ & -0.09 & -0.07 \\
\hline & $r_{G}$ & $0.61^{++}$ & -0.11 & -0.10 & $-0.48^{++}$ & $0.63^{++}$ & 0.02 & -0.25 & $0.78^{++}$ & -0.14 & -0.08 \\
\hline & $\mathrm{r}_{\mathrm{E}}$ & -0.16 & -0.11 & 0.08 & 0.16 & $0.20^{+}$ & $0.15^{+}$ & -0.18 & -0.16 & 0.06 & 0.00 \\
\hline \multirow{3}{*}{ HFPI } & $\mathrm{r}_{\mathrm{F}}$ & & 0.17 & -0.19 & $-0.49^{* *}$ & 0.01 & $-0.33^{*}$ & -0.03 & $0.44^{* *}$ & $-0.31^{*}$ & -0.10 \\
\hline & $r_{G}$ & & 0.19 & -0.24 & $-0.66^{++}$ & -0.06 & -0.38 & -0.07 & $0.61^{++}$ & -0.40 & -0.10 \\
\hline & $r_{\mathrm{E}}$ & & 0.14 & -0.09 & $-0.23^{+}$ & 0.13 & $-0.25^{++}$ & $0.22^{+}$ & 0.03 & $-0.21^{+}$ & -0.12 \\
\hline \multirow{3}{*}{ FPH } & $\mathrm{r}_{\mathrm{F}}$ & & & 0.19 & 0.13 & -0.05 & 0.17 & 0.20 & -0.15 & 0.29 & 0.04 \\
\hline & $r_{G}$ & & & 0.19 & 0.23 & -0.10 & 0.25 & 0.22 & -0.16 & $0.50^{+}$ & 0.05 \\
\hline & $r_{E}$ & & & 0.18 & -0.10 & 0.07 & 0.02 & 0.06 & -0.12 & -0.10 & -0.01 \\
\hline \multirow{3}{*}{ LLP } & $r_{F}$ & & & & 0.20 & 0.17 & 0.10 & 0.26 & -0.20 & $0.46^{* *}$ & $-0.38^{*}$ \\
\hline & $r_{G}$ & & & & 0.24 & 0.13 & 0.00 & 0.31 & -0.22 & $0.61^{++}$ & $-0.51^{++}$ \\
\hline & $\mathrm{r}_{\mathrm{E}}$ & & & & 0.10 & $0.29^{++}$ & $0.36^{++}$ & $-0.20^{+}$ & -0.13 & $0.16^{+}$ & $0.32^{+}$ \\
\hline \multirow{3}{*}{ TNPP } & $\mathrm{r}_{\mathrm{F}}$ & & & & & -0.01 & $0.75^{* *}$ & -0.30 & $-0.61^{* *}$ & 0.30 & 0.07 \\
\hline & $r_{G}$ & & & & & 0.02 & $0.70^{++}$ & -0.37 & $-0.87^{++}$ & 0.11 & 0.08 \\
\hline & $r_{E}$ & & & & & -0.06 & $0.83^{++}$ & -0.08 & 0.09 & $0.56^{++}$ & 0.07 \\
\hline \multirow{3}{*}{ NSP } & $\mathrm{r}_{\mathrm{F}}$ & & & & & & $0.55^{* *}$ & $-0.43^{* *}$ & 0.17 & 0.24 & 0.26 \\
\hline & $r_{G}$ & & & & & & $0.79^{++}$ & $-0.48^{++}$ & 0.20 & 0.38 & 0.28 \\
\hline & $r_{E}$ & & & & & & 0.13 & $-0.33^{++}$ & 0.09 & 0.01 & $0.20^{+}$ \\
\hline \multirow{3}{*}{ NSPL } & $\mathrm{r}_{\mathrm{F}}$ & & & & & & & $-0.52^{* *}$ & $-0.37^{*}$ & $0.42^{* *}$ & $0.42^{* *}$ \\
\hline & $r_{G}$ & & & & & & & $-0.67^{++}$ & $-0.54^{++}$ & 0.22 & $0.49^{+}$ \\
\hline & $\mathrm{r}_{\mathrm{E}}$ & & & & & & & $-0.23^{+}$ & -0.01 & $0.66^{++}$ & $0.32^{++}$ \\
\hline \multirow{3}{*}{ GW } & $r_{F}$ & & & & & & & & 0.22 & $0.35^{*}$ & $-0.37^{*}$ \\
\hline & $\mathrm{r}_{\mathrm{G}}$ & & & & & & & & 0.24 & $0.51^{+}$ & $-0.38^{+}$ \\
\hline & $r_{E}$ & & & & & & & & 0.03 & -0.13 & $-0.27^{+}$ \\
\hline \multirow{3}{*}{ CYCLE } & $\mathrm{r}_{\mathrm{F}}$ & & & & & & & & & -0.07 & -0.23 \\
\hline & $r_{G}$ & & & & & & & & & -0.10 & -0.24 \\
\hline & $\mathrm{r}_{\mathrm{E}}$ & & & & & & & & & 0.00 & $-0.21^{+}$ \\
\hline \multirow{3}{*}{ YIELD } & $\mathrm{r}_{\mathrm{F}}$ & & & & & & & & & & 0.12 \\
\hline & $r_{G}$ & & & & & & & & & & 0.02 \\
\hline & $r_{E}$ & & & & & & & & & & $0.46^{++}$ \\
\hline
\end{tabular}

${ }^{1 /} \mathrm{NDF}=$ number of days to flowering; HFPI = height of insertion first pod; FPH = final plants height; LLP = longitudinal length of pods; $\mathrm{TNPP}=$ total number of pods per plant; NSP = number of seeds per pod; NSPL = number of seeds per plant; GW = grain weight; CYCLE $=$ cycle in days; YIELD $=$ grain yield; HECTO $=$ hectoliter weight. ${ }^{* *}$ : significant to $1 \%$ probability level; ${ }^{*}$ significant to $5 \%$ probability level; ${ }^{++}$: significant to $1 \%$ probability level and ${ }^{+}$: significant to $5 \%$ probability level by Bootstrap Method. 
of significance level ( 0.01 or 0.05$)$. Only $1.82 \%$ of correlations were considered strongly; $21.82 \%$ moderate; $34.55 \%$ mild; and $41.81 \%$ really mild. Regarding accumulated percentage of correlations, only $23.64 \%$ fit between moderate and strong. For COIMBRA et al. (2000) such correlations determine the association between traits from environmental and genetic effects, being responsible for inheritable fraction in progenies.

Genotypic correlation presented large phenotypic ratio, by bootstrap method with 1000 simulations. Between genetic and environmental correlations occurred difference in signals to $32.73 \%$ of combinations, indicating that the causes of genetic and environmental variation influenced the traits through different physiological mechanisms (FALCONER, 1981). In genotypic classification $30.91 \%$ were significant by " $t$ " Test, independent of statistical significance $(0.01$ or 0,05$)$, whit $9.09 \%$ considered strong; $25.45 \%$ moderate; $30.91 \%$ mild; and $34.55 \%$ really mild and accumulated percentage, $34.54 \%$, fit between moderate and strong.

Number of days to flowering (NDF) presented strong significant correlations with cycle (CYCLE) (0.78), moderate for total number of pods per plant (TNPP) (-0.48), height of insertion first pod (HFPI) (0.61) and number of seeds per pod (NSP) (0.63), ranging from very mild and mild to other evaluated traits. Traits from strong to moderate correlation present greater importance in early selections of common bean accessions, being used as a basis for correct selection of these genotypes through indirect selection. According to RIBEIRO et al. (2001) it is possible to obtain gains through indirect selection, if one or more traits present favorable genetic correlation.

For plant height $(\mathrm{PH})$, correlation with grain yield (YIELD) was classified as moderate, and showed positive correspondence to most of evaluated traits, except for NSP and cycle. Longitudinal length of pods (LLP), number of seeds per pod (NSP), cycle (CYCLE) and hectoliter weight (HECTO) were traits that showed lower correlation with final plants height (FPH). Second to MONTARDO et al. (2003) the reason for low correlation between variables is the occurrence of low variability in one of them, since this kind of analysis aims to identify a possible an eventual association on the variation of studied traits.

Significant combinations formed were classified in strong, with positive correlations for total number of pods per plant with number of seeds per plant $(0.70)$ and number of seeds per pod with number of seeds per plant (0.79). Strong and negative correlation was reported only between total number of pods per plant and cycle $(-0.87)$. Most genotype correlations were higher than phenotypic correlations and with same signal, indicating a minor environment influence on the traits expression. These results are consistent with those obtained in other studies, conducted for instance for ALMEIDA et al. (2010) and NOGUEIRA et al. (2012).

Correlations formed by the combination between number of days to flowering and number of seeds per plant, total number of pods per plant with number of seeds per plant and grain yield, longitudinal length of pods with number of seeds per pod and number of seeds per plant, number of seeds per pod and grain yield, and grain yield with hectoliter weight showed magnitude of genotypic correlation coefficients smaller than phenotypic ones. Phenotypic correlations with greater values, indicates that phenotypic expression is reduced due to environmental influences. In this way, phenotypic correlations may be useful in the absence of genotype correlations estimates (ZOZ, 2012).

Magnitudes of genotypic correlations were higher than phenotypic ones for most traits analyzed, demonstrating greater importance of genotypic component than environment component for traits expression, indicating the possibility of success in indirect selection for a desired characteristic.

From a total of 55 environmental correlations formed, $38.18 \%$ were significant to 0.01 or 0.05 of significance level by Bootstrap method with 1000 simulations. In several traits, environmental correlations presented difference in magnitude and sign, in relation to phenotypic and genotypic correlations, where sign and magnitude difference indicates that the environment may interfere with the direct selection (FALCONER, 1981).

Although, presenting expressive useful in quantifying the magnitude and direction of components influence in the determination of main traits, correlation coefficients do not provide the relative importance of direct and indirect effects of such components (SILVA et al., 2009). These may be determined through path analysis, unfolding the correlation coefficient for studied traits, in direct and indirect effect, providing greater reliability in interpretations of cause and effect between compared traits.

Determination coefficient $\left(\mathrm{R}^{2}\right)$ of path analysis was equivalent to $71.6 \%$ indicating that grain yield may be explained by the effects of analyzed traits. Direct and indirect effects of number of days to flowering, height of insertion first pod, final plants height, longitudinal length of pods, total number of pods per plant, number of seeds per pod, number 
of seeds per plant, grain weight, cycle and hectoliter weight traits over standard variable (grain yield) ranged in magnitude and sign. Estimates of direct effects of traits over grain yield showed that number of seeds per plant (0.801) and grain weight (0.641) traits showed larger estimates of direct effects, with high values of magnitude and positive, demonstrating the existence of a strong association between the traits (Table 3).

Positive direct effects were observed for height of insertion first pod, cycle, hectoliter weight and longitudinal length of pods traits, ranging from 0.008 to 0.343 , compensating direct effects of number of seeds per plant, final plants height, number of seeds per pod and number of days to flowering traits, because of its low and negative magnitude, evidencing the low contribution of these variables over grain yield. BARILI et al., (2011), studying the direct effects of components over grain yield in common bean crop, also obtained similar values, evidencing that direct effects for this crop are expressive predictors of genetic correlation, enabling selection for grain yield through its primary components.

For number of seeds per plant and grain weight traits it was observed higher values in the indirect effect ( 0.421 and 0.354 respectively), as in correlation ( 0.801 and 0.641 respectively). This result allowed inferring that genotypes with greatest grain yield may be obtained from the indirect selection of genotypes with higher number of seeds per plant and increased grain weight. Number of days to flowering
(-0.090), height of insertion first pod (-0.315) and cycle (-0.068) presented indirect effects of negative correlation and low magnitude with grain yield. Positive correlations were reported for remaining studied traits, especially longitudinal length of pods and number of seeds per plant presenting moderate correlation, higher than 0.4 . Total number of pods per plant presented low and negative correlation with grain yield $(-0.128)$. However, the same had indirect effect of high magnitude through number of seeds per plant over grain yield (0.602). Thus, selection based only on total number of pods per plant will not be effective, becoming interesting to conduct simultaneous selection for total number of pods per plant and number of seeds per plant. CRUZ \& REGAZZI (2001) pointed out that for improvement purposes it is important to verify between the traits that have high correlation with the main variable, those of greatest direct effect in favorable sense to selection, such that the correlated response by using indirect selection could be efficient.

\section{CONCLUSION}

Magnitudes of genotypic correlations were higher than phenotypic ones for most analyzed traits, demonstrating greater importance of genotypic component than environment component for traits expression, indicating the possibility of success in indirect selection for a desired characteristic.

Table 3 - Direct and indirect effects of primary variables (NDF, HFPI, FPH, LLP, TNPP, NSP, NSPL, GW, CYCLE and HECTO) over basic variable (YIELD) in 40 common bean traditional accesses (Caceres-MT. 2013).

\begin{tabular}{|c|c|c|c|c|c|c|c|c|c|c|c|}
\hline \multirow{2}{*}{ Traits } & \multirow{2}{*}{$\begin{array}{l}\text { Direct } \\
\text { Effect }\end{array}$} & \multicolumn{10}{|c|}{ 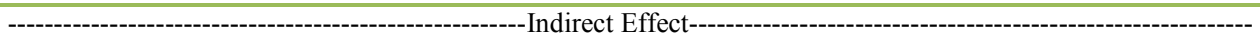 } \\
\hline & & NDF & HFPI & FPH & LLP & TNPP & NSP & NSPL & GW & CYCLE & HECTO \\
\hline \multicolumn{12}{|c|}{ 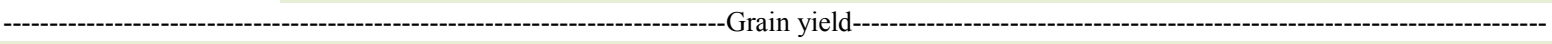 } \\
\hline NDF & -0.040 & & -0.036 & -0.001 & -0.028 & 0.043 & -0.027 & 0.033 & -0.157 & 0.141 & -0.016 \\
\hline HFPI & -0.085 & -0.017 & & 0.001 & -0.066 & 0.063 & -0.0004 & -0.261 & -0.020 & 0.092 & -0.021 \\
\hline FPH & 0.008 & 0.004 & -0.015 & & 0.065 & -0.016 & 0.003 & 0.138 & 0.128 & -0.031 & 0.009 \\
\hline LLP & 0.343 & 0.003 & 0.016 & 0.001 & & -0.025 & -0.008 & 0.084 & 0.165 & -0.042 & -0.081 \\
\hline TNPP & -0.128 & 0.013 & 0.042 & 0.001 & 0.068 & & 0.0004 & 0.602 & -0.188 & -0.126 & 0.016 \\
\hline NSP & -0.051 & -0.021 & -0.001 & -0.0004 & 0.057 & 0.001 & & 0.438 & -0.274 & 0.036 & 0.056 \\
\hline NSPL & 0.801 & -0.002 & 0.028 & 0.001 & 0.036 & -0.096 & -0.028 & & -0.332 & -0.077 & 0.089 \\
\hline GW & 0.641 & 0.010 & 0.002 & 0.001 & 0.088 & 0.037 & 0.022 & -0.415 & & 0.045 & -0.079 \\
\hline CYCLE & 0.207 & -0.027 & -0.038 & -0.001 & -0.070 & 0.078 & -0.009 & -0.297 & 0.140 & & -0.050 \\
\hline HECTO & 0.214 & 0.003 & 0.008 & 0.0003 & -0.129 & -0.009 & -0.013 & 0.335 & -0.235 & -0.048 & \\
\hline \multicolumn{2}{|c|}{ Total Effect } & -0.090 & -0.315 & 0.292 & 0.457 & 0.302 & 0.302 & 0.421 & 0.354 & -0.068 & 0.124 \\
\hline \multicolumn{2}{|c|}{ Determination $\left(\mathrm{R}^{2}{ }_{0.123}\right)$} & & 0.716 & & & & & & & & \\
\hline \multicolumn{2}{|c|}{ Residual Effect $\left({ }_{\rho^{\wedge}} \epsilon\right)$} & & 0.533 & & & & & & & & \\
\hline
\end{tabular}

${ }^{1 /} \mathrm{NDF}=$ number of days to flowering; HFPI = height of insertion first pod; FPH = final plants height; LLP = longitudinal length of pods; $\mathrm{TNPP}=$ total number of pods per plant; NSP = number of seeds per pod; NSPL = number of seeds per plant; GW = grain weight; CYCLE $=$ cycle in days; YIELD = grain yield HECTO = hectoliter weight. 
Genetic correlations and path analysis indicated that number of seeds per plant and grain weight showed more favorable effect over grain yield and may be used in the selection for grain yield in common bean crop, favoring not only the local program, but other breeding programs with this crop.

\section{ACKNOWLEDGMENTS}

Authors were sponsored by Universidade do Estado do Mato Grosso (UNEMAT), Fundação de Amparo a Pesquisa do Estado de Mato Grosso (FAPEMAT) and Coordenação de Aperfeiçoamento de Pessoal de Nível Superior (CAPES).

\section{REFERENCES}

ALMEIDA, R.D. et al. Phenotypic, genotypic and environmental correlations in soybean cultivated under an irrigated meadow in south of Tocantins state. Bioscience Journal, v.26, n.1, p.95-99, 2010. Available from: <http:// http://www.seer.ufu.br/index.php/bioscience journal/article/view/7044/4670>. Accessed: Aug. 01, 2016.

AMORIM, E.P. et al. Correlations and path analysis in sunflower. Bragantia, v.67, n.2, p.307-316, 2008. Available from: $<$ http://dx.doi. org/10.1590/S0006-87052008000200006>. Accessed: Aug. 01, 2016.

ARANTES, E.M. et al. Changes in soil chemical attributes cultivated in the organic system with no-tillage in different coverage plants. Revista Agrarian, v.5, n.15, p.47-54, 2012. Available from: <http://www.periodicos.ufgd.edu.br/index.php/ agrarian/article/view/563/101 2>. Accessed: Aug. 01, 2016.

BARILI, L.D. et al. Phenotypic correlation between yield components of common bean (Phaseolus vulgaris L.). Semina: Ciências Agrárias, v.32, n.4, p.132-138, 2011. Available from: $<$ https://www.cabdirect.org/cabdirect/abstract/20123189420>. Accessed: Aug. 01, 2016. doi: 10.5433/1679-0359.

CABRAL, P.D.S. et al. Genetic diversity of common bean accessions by agronomic traits. Revista Ciência Agronômica, v.42, n.4, p.898-905, 2011. Available from: <http://dx.doi.org/10.1590/ S1806-66902011000400011>. Accessed: Aug. 01, 2016.

COIMBRA, J.L.M. et al. Canonical correlations: II - analisys of bean yield and yield components. Ciência Rural, v.30, n.1, p.31-35, 2000. Available from: <http://dx.doi.org/10.1590/S010384782000000100005>. Accessed: Aug. 01, 2016.

CONAB (COMPANHIA NACIONAL DE ABASTECIMENTO). Acompanhamentodesafrabrasileira:grãos, safra2012/2013-Décimo segundo levantamento setembro 2013. Available from: <http://www. conab.gov.br/OlalaCMS/uploads/arquivos/13 $06 \quad 06 \quad 09 \quad 0927$ boletim_graos_- junho_2013.pdf $>$. Accessed: Aug. 01, 2016.

CRUZ, C.D. GENES - a software package for analysis in experimental statistics and quantitative genetics. Acta Scientiarum, v.35, n.3, p.271-276, 2013. Available from: $<$ http://periodicos.uem. br/ojs/index.php/ActaSciAgron/article/view/21251>. Accessed: Aug. 01, 2016. doi: 10.4025/actasciagron.v35i3.21251.

CRUZ, C.D.; REGAZZI A.J. Modelos biométricos aplicados ao melhoramento. 2.ed. Viçosa: UFV, 2001. 390p.

CRUZ, C.D. et al. Modelo biométrico aplicado ao melhoramento genético. 4.ed. Viçosa: UFV, 2012. V.1, 514p.

FALCONER, D.S. Introdução à genética quantitativa. Viçosa: UFV, 1981. 279p

FAO. Faostat database gateway. Food and Agricultural commodities production. Base 2012. Available from: <http:// faostat.fao.org/site/339/default.aspx>. Accessed: Aug. 01, 2016.

MONTARDO, D.P. et al. Path analysis for seed production in red clover (Trifolium pratense L.). Revista Brasileira de Zootecnia, v.32, n.5, p.1076-1082, 2003. Available from: <http://dx.doi.org/10.1590/ S1516-35982003000500007>. Accessed: Aug. 01, 2016.

NEVES, S.M.A.S. et al. Characterization of climatic conditions from Caceres/MT, Brazil, from 1971 to 2009: subsidy for agricultural activities and tourist city. Boletim Goiano de Geografia, v.31, n.2, p.55-68, 2011. Available from: <http://www.redalyc.org/ html/3371/337127156004/>. Accessed: Aug. 01, 2016. doi: 10.5216/ bgg.V31i2.16845.

NOGUEIRA, A.P.O. et al. Path analysis and correlations among traits in soybean grown in two dates sowing. Bioscience Journal, v.28, n.6, p.877-888, 2012. Available from: $<$ http://www.seer.ufu.br/index.php/ biosciencejournal/article/view/14576>. Accessed: Aug. 01, 2016.

RIBEIRO, N.D. et al. Genetic correlations of morpho-agronomic characters and implications in the selection of carioca bean genotypes. Revista Brasileira Agrociência, v.7, n.2, p.93-99, 2001. Available from: $<$ https://periodicos.ufpel.edu.br/ojs2/index. php/CAST/article/ download/379/372>. Accessed: Aug. 01, 2016.

SHIMAKURA, S.E.; RIBEIRO JÚNIOR, P.J. Estatística descritiva: interpretação do coeficiente de correlação. Curitiba: Departamento e Estatística da UFPR, 2012.

SILVA, D.V.F. Seleção de linhagens de feijoeiro Type rosinha resistentes à antracnose, à mancha angular e de boa cocção. 2007. 71f. Dissertação (Mestrado em Genética e Melhoramento de plantas) - Universidade Federal De Lavras, MG.

SILVA, F.L. et al. Path analysis for yield components of sugarcane via BLUP. Revista Ceres, v.56, n.3, p.308-314, 2009. Available from: $<$ http://www.ceres.ufv.br/ojs/index.php/ceres/article/view/3429/1331>. Accessed: Aug. 01, 2016.

ZOZ, T. Correlação e análise de trilha de produtividade de grãos e seus componentes e caracteres de planta em cártamo (Carthamus tinctorius L.) e mamona (Ricinus communis L.). 2012. 56f. Dissertação (Mestrado em Agronomia) - Universidade Estadual de São Paulo, SP. 